\title{
A COMMON EUROPEAN SONG HERITAGE IN THE NINETEENTH CENTURY SONGS OF IRELAND AND GERMANY
}

\section{DAVID ROBB}

This paper deals with thematic similarities between German and Irish folk songs of the nineteenth century, particularly the period surrounding the 1848 Revolution. While clear commonalities can be seen to exist in songs about exploitative masters, hunger, emigration and army recruitment, there are differences in terms of the situation of Germany as a rapid industrialising nation while Ireland was still rural. At the same time the plight of the displaced German craftsmen due to industrialisation does have echoes in the struggles of the craft trade expressed in the Irish songs. Another difference lies in the dimension of religion and national liberation in the Irish ballads, whereas the German counterparts display more of a developing class consciousness. While the German and Irish narrative styles and approaches also differ from one another, there is nonetheless evidence of a common folk language and musical heritage between the two countries, which has been affirmed by the cultural exchange between their respective folk movements since the 1970s.

Keywords: folk song, folk revival 1848 Revolution, Industrial Revolution, famine, emigration, anti-militarism, drinking ballads, travelling craftsmen.
Članek obravnava vsebinske podobnosti med nemškimi in irskimi ljudskimi pesmimi iz 19. stoletja, posebej še iz časa okrog revolucionarnih sprememb leta 1848. Medtem ko lahko opazimo izrazite podobnosti v pesmih, ki pojejo o izkoriščevalskih gospodarjih, emigraciji in vojaških vpoklicih, pa so opazne razlike med Nemčijo kot deželo izrazite indistrializacije in Irsko kot še vedno zelo ruralno deželo. Istočasno pa težak položaj zaradi industrializacije razseljenih nemških rokodelcev odmeva $v$ tistih irskih pesmih o rokodelstvu. Druga je razlika v religiji in nacionalni osvoboditvi, kakor odsevata $v$ irskih baladah, medtem ko nemške balade bolj izražajo razvijajočo se razredno zavest. Tudi pripovedna struktura in slog obeh nacionalnih tradicij se razlikujeta, sta pa kljub temu opazna podoben jezik in glasbeno izrocilo, karje potrdila kulturna izmenjava med irskim in nemškim preporodom ljudskega od leta 1970 naprej.

Ključne besede: ljudska pesem, preporodna glasba revolucionalrnega 1848, industrijska revolucija, lakota, izseljevanje, antimilitarizem, "pivske balade", potujoči rokodelci.

In the search for a European heritage of folk song one potential source of discovery is the era of the revolution which affected several European countries in 1848 and 1849. Particularly in the folk song traditions of Ireland and Germany in the decades leading up to and after 1848 one comes across many overlapping themes such as nationhood, political emancipation, hunger, exploitation, military service and mass emigration.

Before focusing on the aspects in common of these two song cultures it is important to outline the parallels and differences in the political and national contexts. Ireland, a rural country embroiled in religious conflict, was under control of the British Crown, its peasants in the clutches of exploitative British landlords and further impoverished by famine, its trade dictated to by British markets. Germany on the other hand was experiencing its industrial revolution: it had an ascending bourgeois class seeking political emancipation from the ruling aristocracy and a growing proletarian class displaced from the countryside, living in wretched conditions and also intermittently suffering from hunger. 
In both these contexts it is the expressions of rage, helplessness, longing and sadness relating to common themes such as hunger, political persecution and emigration, which make a comparison of these two European song traditions relevant. In the 1840s harvests failed across Europe on several occasions causing widespread distress and resulting in mass emigration to America. Three million of the eight million total population left Ireland for the USA within 50 years in the nineteenth century. Millions fled Germany too, the number even exceeding that which emigrated from Ireland. As Robert L. Wright observes: "Only the Germans came [to America] in larger numbers than the Irish" (Wright 1975:7).

Much of the source material for this article has come from Wolfgang Steinitz's anthology Deutsche Volkslieder demokratischen Charakters aus sechs Jahrhunderten (1979) and Robert L. Wright's collection Irish Emigrant Ballads and Songs (1975). A more immediate source, however, has come from the songs of the Irish and German folk revivals recorded from the 1960s. Indeed in the last fifty years the closeness of the relationship between German and Irish (as well as Scottish) song has been underlined by the connections between the folk scenes of both countries. While this relationship is at times one-sided Irish audiences generally do not reciprocate the interest in German folk that the Germans have for Irish folk - the great presence of Irish folk groups in Germany since the 1970s has highlighted the musical and thematic parallels.

West Germany began its relationship with the folk music of other countries in the early 1960s. This was partly an expression of the international folk music boom linked to the anti-nuclear and protest movements of the Western Europe and America embodied by singers such as Bob Dylan, Joan Baez and Pete Seeger. It spurned a new generation of folk singers in West Germany. In particular young singers were reappraising their relationship to their own folk culture which due to the political appropriation of folk song by the Nazis now had definite conservative connotations. In this respect German singers saw in Irish folk music (as well as in international folk song in general) a gesture of defiance and an expression of freedom not associated with their own culture. However, inspired by the song collector Wolfgang Steinitz, singers in the German Youth Movement such as Peter Rohland and Hein and Oss Kröher realised that Germany did in fact have its own tradition of rebellious folk song. It had been banned by the Nazis and thoroughly neglected after the war because of the blanket associations of all folk culture with the Nazis. To counter this prejudice Steinitz, working in the 1950s in East Germany, had coined the term "democratic" German folk song as opposed to the conservative "volkstümlich" song. Between 1954 and 1962 he brought out the anthology Deutsche Volkslieder demokratischen Charakters. This work became a major reference point in the revival of the German democratic folk song in the 1960s around the annual Burg Waldeck festivals in West Germany and over a decade later in the GDR (see Robb 2007: 11-34).

By the 1970s as the folk revival in Germany picked up momentum the common aspects between German and Irish folk song were emphasised by the new Celtic-influenced accompaniments which included guitars, fiddles, whistles and mandolins and the authentic, 
untrained folk singing style (see for example the group Fidel Michel). In this way, formally as well as thematically via the gesture of protest, traditional German Volkslieder were transformed into contemporary folk-songs with a political edge. Correspondingly there was a sense of a common folk language and musical heritage between the two cultures.

One of the most well known songs expressing the plight of the German worker in the 1840 s is "Das Blutgericht". This was recorded by many German artists including Rohland, Dieter Süverkrüp and the Kröher twins. An anonymous protest song, it expressed the misery of the Silesian weavers immediately before their uprising in June 1844. It is a personal attack on the local factory owners who due to international competition (particularly from Britain) in the weaving industry kept reducing the weavers' wages to the point where they could no longer afford to feed themselves. Here are five characteristic verses from the 24-verse song:

Hier im Ort ist das Gericht,

Viel schlimmer als die Fehmen,

Wo man nicht nur das Urteil spricht,

Das Leben schnell zu nehmen.

Hier wird der Mensch langsam gequält,

Hier ist der Folterkammer,

Hier werden Seufzer viel gezählt

Als Zeugen von dem Jammer.

Die Herren Zwanziger die Henker sind

Die Dierig ihre Schergen.

Davon ein jeder tapferschind't,

Anstatt was zu verbergen.

Ihr Schurken all, ihr Satansbrut,

Ihr höllischen Kujone,

Ihr freßt der Armen Hab und Gut,

Und Fluch wird euch zum Lohne.

Ihr seid die Quelle aller Not,

Die hier den Armen drücket,

Ihr seid's, die ihm das trockne Brot

Noch von dem Munde rücket. ${ }^{1}$

\begin{abstract}
A blood court is what we have here
harsher than Vehmic law

with verdicts cruelly more severe

than death plain, swift, and raw.
\end{abstract}

Relentless torture is our fate,

and we are on the rack.

Hear our sighs from morn to late

while they are on our back.

The Zwanzigers execute all day,

The Dierigs by their side.

They grind us, sweat us, skin and flay,

and nothing do they hide.

You villains, oh, you devil's brood,

Infernal monsters you,

getting fat off the poor man's good-

damnation will be your due.

It's you who cause pain, grief despair

for the poor man in this land,

and even snatch with zero care

his dry bread from his hand.

It is difficult to find such a politically focussed expression of class conflict in the Irish protest songs of the time. This stems from the fact that Ireland was a rural nation, and a working class consciousness, which was currently forming in the new industrial Germany abetted by the writing of Karl Marx, scarcely existed there. There were, however, songs

1 Pinkert-Saelzer (ed.) 1997, 25-26; see also Rohland 1967, order number: T75508. 
relating to Irish weavers. The Irish rural weaving industry had experienced hardship as a result of British penetration of markets between 1780 and 1835 facilitated by the technological innovation of its Industrial Revolution (O'Hearne 2001: 93). Wright's collection of Irish ballads contains a song "The Distressed Sons of Erin" which mentions the plight of the weaver who is forced to emigrate. Unlike "Das Blutgericht" this is not a tirade against the oppressors but rather expresses the general situation of distress, lamenting, for example, the rates and taxes (demanded by landlords and the British government which are not named) and at the failure of Catholics and Protestants to live and share together. It is noteworthy that unlike German songs of distress this one is bound up with a strong sense of national identity:

Sweet Erin, my country, how long wilt thou grieve,

Exhausted and torn, no hopes of relief,

Your bright shining sons to America are bound,

That land of sweet Union, where freedom is found,

Our builders are down, that staple fine trade,

By which our poor labourers and others got bread,

The industrious weaver so cold in his home,

For want of employment is obliged to roam.

[...]

By rates and by taxes we're nearly undone,

What a rent do we pay for the light of the sun,

Here my dear countrymen were burdened together,

And what is still worse, we envy each other;

The distress of our countrymen reaches to all,

The tradesmen, the labourer, the great and the small,

No difference of religion, no bribery or gain,

Should make us to quarrel, when our burthen's the same.

$[\ldots]^{2}$

In the "Lament of the Evicted Irish Peasant", a more harrowing, personal sounding account, there is almost a sense of fate, an acceptance of the hopelessness of the situation. The unfeeling landlord is mentioned but not cursed. Unlike "Das Blutgericht", which Karl Marx had described as an indication of a growing class consciousness among the German workers, this Irish song of woe is firmly rooted in the culture of a highly religious peasantry:

The night is dark and dreary,

A gradh geal mo chroidhe! (oh, dear love of my heart)

2 Wright 1975: 43, source: Broadside, no imprint, British Museum. 
And the heart that loves you weary,

A gradh geal mo chroidhe!

For every hope is blighted,

That bloomed when first we plighted

Our troth, and were united,

A gradh geal mo chroidhe!

Twas famine's wasting breath,

A gradh geal mo chroidhe!

That winged the shaft of death,

A gradh geal mo chroidhe!

And the landlord, lost to feeling,

Who drove us from our sheeling,

Though we prayed for mercy kneeling,

A gradh geal mo chroidhe!

$[\ldots]^{3}$

One of the most famous Irish songs relating to the famine is "Skibbereen. A Ballad of the Famine" (Wright 1975: 54). It is written from the retrospective vantage point of American emigration. Unlike the above song, here a clear political consciousness has been formed, the enemy, on which revenge will one day be enacted, is named, and there are no religious undertones or helpless expressions of fate. It is a father and son dialogue focussing on the reasons why a family was forced to leave its beloved town and country. This particular version contains an extra verse relating to the failed uprising of 1848 in Ireland in which the father had taken part and was henceforth branded as a traitor to the Crown. This verse explains why it was impossible for the son to be left with friends namely because he bore his father's name.

"O father dear, I oft-times hear you talk of Erin's Isle,

Her lofty scenes and valleys green, her mountains rude and wild.

They say it is a pretty place wherein a prince might dwell.

And why did you abandon it, -- the reason to me tell."

"My son, I loved our native land with energy and pride,

Until a blight came on my land, my sheep and cattle died.

The rent and taxes were to pay, I could not them redeem,

And that's the cruel reason why I left old Skibbereen."

Wright 1975: 46, from Sparling 1888: 205-206. 
"Oh it's well I do remember that bleak December day,

The landlord and the sheriff came to drive us all away.

They set my roof on fire with their demon yellow spleen,

And that's another reason why I left old Skibbereen.

Your mother too, (God rest her soul) lay on the snowy ground,

She fainted o'er in anguish with the desolation round.

She never rose. But passed away from life to immortal dream,

And found a quiet grave, my boy, in dear old Skibbereen."

"And you were only two years old and feeble was your frame.

I could not leave you with your friends, you bore your father's name.

I wrapped you in my cottamore at the dark of night unseen.

I heaved a sigh and bid goodbye to dear old Skibbereen."

"It's well I do remember the year of forty-eight

When I arose with Erin's boys to battle 'gainst the fate.

I was hunted thro' the mountains like a traitor to the Queen,

And that's another reason why I left old Skibbereen."

"O father dear, the day will come when vengeance loud will call,

And we will rise with Erin's boys to rally one and all.

I'll be the man to lead the van beneath our flag of green,

And loud and high will raise the cry "Revenge for Skibbereen." 4

Outside of Ireland one of the worst affected areas of famine was Germany particularly the lower Rhine. In 1847 there were food riots in many towns including Berlin, Stuttgart, Stettin, Breslau, Halle, Posen, Hamburg and Chemnitz. In their book Glasbruch 1848. Flugblattlieder und dokumente einer zerbrochenen Revolution Barbara James and Walter Mossmann feature a hunger song "Mamele, Mamele, gib mir Brot." They found a version of it from Steinhofen near Hechingen. Void of political references, in its simple rhymes, rhythms and role-play it is reminiscent of a children's playground chant. The content - a starving child pleading for food from a helpless mother - is, however, harrowing:

4 Wright 1975: 54, from Herbert Hughes: Irish Country Songs. 2 vols. London: Boosey \& Co., 1915, 76-84. 
"Mamele, Mamele, gib mir Brot Oder ich sterb Hungersnot!" "Warte nur, mein liebes Kind, Morgen will ich säen.” Als das Korn gesäet war, Stand das Kind schon wieder da:

"Mamele, Mamele, gib mir Brot Oder ich sterb Hungersnot!" "Warte nur, mein liebes Kind, Morgen will ich schneiden." Als das Korn geschnitten war Stand das Kind schon wieder da:

"Mamele, Mamele, gib mir Brot Oder ich sterb Hungersnot!" "Warte nur, mein liebes Kind, Morgen will ich heimführen." Als das Korn heimgeführt war, Stand das Kind schon wieder da:

"Mamele, Mamele, gib mir Brot Oder ich sterb Hungersnot!" "Warte nur, mein liebes Kind, Morgen will ich dreschen." Als das Korn gedroschen war, Stand das Kind schon wieder da:

"Mamele, Mamele, gib mir Brot Oder ich sterb Hungersnot!" "Warte nur, mein liebes Kind, Morgen will ich mahlen." Als das Korn gemahlen war, Stand das Kind schon wieder da:

"Mamele, Mamele, gib mir Brot Oder ich sterb Hungersnot!" "Warte nur, mein liebes Kind, Morgen will ich backen." Als das Korn gebacken war, Da lag das Kind im Felsengrab. ${ }^{5}$
Mummy dear, mummy dear give me bread Or I'll die of hunger!

"Wait a while my dear child, Tomorrow I'll go sowing."

But when the corn was sown, The child asked yet again:

Mummy dear, mummy dear give me bread Or I'll die of hunger!

"Wait a while my dear child,

Tomorrow I'll go cutting."

But when the corn was cut,

The child asked yet again:

Mummy dear, mummy dear give me bread

Or I'll die of hunger!

"Wait a while my dear child, Tomorrow I'll take it home."

But when the corn was taken home,

The child asked yet again:

Mummy dear, mummy dear give me bread Or I'll die of hunger!

"Wait a while my dear child, Tomorrow I'll go threshing."

But when the corn was threshed, The child asked yet again:

Mummy dear, mummy dear give me bread Or I'll die of hunger!

"Wait a while my dear child,

Tomorrow I'll go grinding."

But when the corn was ground,

The child asked yet again:

Mummy dear, mummy dear give me bread Or I'll die of hunger!

"Wait a while my dear child,

Tomorrow I'll go baking."

But when the corn was baked,

The child lay in the grave. ${ }^{6}$

Another text, a 21-verse epic poem, relating to hunger from this period discovered by James and Mossmann is more satirical, reflecting the wit and cynicism of urban journalism.

5 James and Mossmann1983: 35-37.

6 Translation by David Robb. 
"Der Krawall in Stuttgart vom 3. Mai 1847 oder Aufruhr gegen den Bäcker Mayer, Stuttgart, Hauptstätterstraße wegen zu hoher Brot- und Lebensmittelpreise" points the finger at the hated speculators who bought up grain surpluses in times of plenty only to sell it on the market in times of need for greatly inflated prices: Denn jetzt will ein Volk ich nennen, / Das der Armen Flüche brennen, / Kipperer sind sie genannt / Auf und ab im deutschen Land (James and Mossman 1983: 41).

The following year 1848 was a year of revolutions throughout continental Europe. The February revolution in Paris against King Louis-Philippe of France sent political shock waves across Europe and led to revolts breaking out in Berlin, Vienna, Rome, Prague, and Budapest. For a brief period liberal administrations replaced the absolutist governments and it seemed that a new democratic age of universal suffrage was dawning. Two songs from Germany and Ireland respectively capture this utopian spirit. The French Revolution of 1789 was invoked by a battle song („Kampllied”) from 1849 called "Reveille” by the German poet Ferdinand Freiligrath. The words were sung to the tune of the French Marseillaise:

Frisch auf zur Weise von Marseille, Frisch auf ein Lied mit hellem Ton! Singt es hinaus als die Reveille

Der neuen Revolution!

Der neuen Revolution!

Der neuen, die mit 'Schwert und Lanze

die letzte Fessel bald zerbricht -

der alten, halben singt es nicht!

Uns gilt die neue nur, die ganze!

Die neue Rebellion!

Die ganze Rebellion!

Marsch! Marsch!

Marsch! Marsch!

Marsch! - Wär's zum Tod!

Und unsre Fahn' ist rot!

[...]
Let's sing a Marseillaise of our own

One that rings as clear as a bell,

Let's sing it as the reveille

Of the new revolution!

The new one whose swords and lances

Will soon break the very last chain.

Let's sing for the new all-out revolution,

Not for some half-measure old one.

The new rebellion!

E'en unto death!

Our flag is red, you see!

$[\ldots]^{7}$

Such a call to arms to overthrow tyrannical oppressors was also expressed in Irish songs of the time. Inspired by revolutionary events of 1848 across Europe, a group known as The Young Irelanders led a delegation to Paris to witness the realities of the new French Republic. They returned to Ireland with the republican tricolour flag, which as well as embodying the emancipatory ideals of the French Revolution was intended as a symbol of reconciliation between the Orange (Protestant) and Green (Catholic) inhabitants. The Young Irelanders' rebellion in County Tipperary in July 1848 against police and troops of the British Government was, as ultimately all other uprisings across Europe, unsuccessful and led to the persecution and emigration of its leaders.

7 Pinkert-Saelzer (ed.) 1997: 44-46 (translator unknown). 
The song "An Irish Marseillaise" has a similar fighting spirit and utopian strain to the German "Reveille" and is also sung to the tune of the French national anthem. Like the previous Irish examples, it is sung from the perspective of the émigrés in America. Although lacking the ideological communist slant of "Reveille" and containing the obligatory reference to God, it nonetheless combines the universalism and emancipatory spirit of the Young Ireland movement with the rage against the injustice of persecution and famine:

Rise! Rise! A glorious day is breaking,

A bleeding country asks our aid,

Our slumbrous slavery forsaking,

Throw off the chains our race degrade!

Throw off the chains our race degrade!

With God and Man our cause sustaining,

By weakness we have given too long

The fight unjust unto the strong,

We'll conquer now, the Right maintaining,

Chorus:

Arise! our night is o'er,

Rise! rise! from shore to shore.

Arise! arise! ere Freedom dies,

For them we'll starve no more!

Columbia! strong angel, aid us, Across the waters hear our cry -

Than live the sad serfs they have made us,

Far better it were we should die!

Far better it were we should die!

Alas, for weeping Freedom's glory,

Behold an ancient, war-spent race,

Unarmed, unshielded, face to face

With Tyranny, mail-clad and gory.

Go tell us who are those our masters,

That should grace their feast as slaves,

Should bear for them all life's disasters,

And, dying, fall in pauper graves!

And, dying, fall in pauper graves!

Are they spoilers of our nation?

Are they the spawn of treacherous foes? 
Are they the flatterers on our woes,

Whose glory is our degradation?

O, Famine Graves! Whose jaws have caught us,

$O$, Ships that sunk us in the sea,

We know the lessons ye have taught us,

No more, no more your prey we'll be!

No more, no more your prey we'll be!

Who says our toils are never-ending?

Who says that we must ever kneel,

A People at a Hireling's heel?

Nay, better die our homes defending. ${ }^{8}$

This song is undoubtedly comparable with "Reveille". Its difference, however, lies in the references to God as well as the national consciousness of long endured subservience to English rule. This knowledge is summed up in the song "The Races of Ballyhooly": "Three centuries the foreign racel has ground us "neath the harrow." "An Irish Marseillaise" laments the "slumberous slavery" which Ireland has suffered. It is significant that this metaphor of sleep finds its opposite in the calls to "Arise!"

The metaphor of sleep is also apparent in many German songs of the period to denote suppression on one hand or political complacency on the other. Resignation in the aftermath of revolutionary defeat is reflected by Georg Herwegh's "Mein Deutschland, strecke die Glieder" written in February 1849. With the metaphor of "sleep" it mocks the retreat into renewed subordination:

Mein Deutschland, strecke die Glieder Ins alte Bett, so warm und weich. Die Augen fallen dir nieder, du schläfriges deutsches Reich.

Hast lange geschrien dich heisernun schenk dir Gott die ewige Ruh! Dich spitzt ein deutscher Kaiser pyramidalisch $z u{ }^{10}$

\author{
My Germany stretch your limbs \\ In your old bed so warm and soft \\ Your eyes are closing on you, \\ You sleepy German Empire \\ You've shouted yourself hoarse - \\ Now God presents you with eternal peace! \\ A German Kaiser moulds you majestically.
}

Probably the most famous German political song using the metaphor of sleep is the "Badisches Wiegenlied" (Lullaby of Baden). Written by Ludwig Pfau it laments the Prussian brutal reprisals in Baden after the defeat of the revolutionary troops at Rastatt in

8 Wright 1975: 65, from Cleary 1888: 16-17.

9 Wright 1975: 70-71, from Donal O'Sullivan: Songs of the Irish. Dublin: Browne and Nolan, 1960, 157-159.

10 Rohland 1967, transl. by D. Robb. 
the summer of 1849. Text and melody evoke the melancholy mood of dashed ideals and the retreat into an private, inner world after the euphoria of initial revolutionary success. It is clear that the effect of the song is based on the stark contrast between the innocent style of the lullaby form and the bitter political content:

Schlaf', mein Kind, schlaf'leis, Dort draußen geht der Preuss!' Deinen Vater hat er umgebracht, Deine Mutter hat er arm gemacht, Und wer nicht schläft in guter Rub', Dem drückt der Preuß' die Augen zu. Schlaf', mein Kind, schlaf' leis, Dort draußen geht der Preuß!!

Schlaf', mein Kind, schlaf' leis, Dort draußen geht der Preuß"! Der Preuß' hat eine blut'ge Hand, Die streckt er über's bad'sche Land, Und alle müssen wir stille sein, Als wie dein Vater unterm Stein. Schlaf', mein Kind, schlaf' leis, Dort draußen geht der Preuß!!

Schlaf', mein Kind, schlaf' leis, Dort draußen geht der Preuß! Zu Rastatt auf der Schanz, Da spielt er auf zum Tanz', Da spielt er auf mit Pulver und Blei, So macht er alle Badener frei. Schlaf', mein Kind, schlaf' leis, Dort draußen geht der Preuß!!

Schlaf', mein Kind, schlaf' leis, Dort draußen geht der Preuß! Gott aber weiß, wie lang' er geht, Bis daß die Freiheit aufersteht, Und wo dein Vater liegt, mein Schatz, Da hat noch mancher Preuße Platz! Schrei, mein Kindlein, schrei's: Dort draußen liegt der Preuß! ${ }^{11}$
Sleep and make no sound, the Prussians are around. They came and killed your father, they came and robbed your mother, and unless you're in slumber deep the Prussians will put you to sleep. Sleep and make no sound, the Prussians are around.

Sleep and make no sound, The Prussians are around. The Prussian has a bloody hand, extends it over Baden land, and we must all hold our breath like your father in his death. Sleep and make no sound, the Prussians are around.

Sleep and make no sound, the Prussians are around. Rastatt bulwark was the site where he played music, played with might With gunpowder and lead played he, and set the people of Baden free. Sleep and make no sound, the Prussians are around.

Scream and yell, my darling dear: the Prussian, the Prussian is lying out here. God will know how much time to give until he lets liberty live, and many a Prussian will yet fit down with your father in the dark pit. Scream and yell, my darling dear: the Prussian, the Prussian is lying out here. ${ }^{12}$

After the suppression of the revolution of $1848 / 49$ in Germany many activists fled to America joining the already large wave of emigration. As in Ireland there are many songs

11 Süverkrüp 1973.

12 Ludwig Pfau: „Badisches Wiegenlied“ (Lullaby of Baden), in: Pinkert-Sältzer 1997: 24. 
documenting the often hazardous journey to America and the difficult conditions which people often encountered when they arrived there. One such song which was popular in the folk song revival of East Germany in the 1980s was "Auswanderer-Lied" ("Émigré's Song") sung by the group Folkländer. The first half of the song documents the material hardships which caused the people to seek to emigrate:

Ich verkauf mein Gut und Häuslein

um ein so geringes Geld

nach Amerika zu ziehen

in den andern Teil der Welt.

Und als wir nach Straßburg kamen

in die wunderschöne Stadt

gingen wir zum Herrn Präfekten

legten unsere Schriften ab.

Herr Präfekt, oh Herr Präfekt,

wir haben eine Bitt an Sie

Sie solln den Paß uns unterschreiben

nach Amerika zu zieh'n.

Was habt ihr für eine Ursach

was habt ihr denn für einen Klag

euer Leben zu riskieren

in dem Land Amerika.

Wir können nicht mehr länger bleiben wir können hier nicht länger sein denn die Herren und Lakaien nehmen uns den größten Teil.
I sell my house and possessions,

For a mere pittance,

To move to America,

The other part of the world.

And when we came to Strasburg,

To the beautiful town,

We went to the prefect,

To hand in our application.

Your honour, oh your honour,

We have one request of you,

Please sign our passes,

So we may leave for America.

What cause do you have,

What sort of complaint,

That you'll risk your life

In the land America?

We cannot stay here any longer,

We cannot live here any more,

For the lords and the notaries

Take everything that we possess.

The second half of the song expresses the misery of shipwreck at sea and speaks of the homesickness experienced on arrival in America:

Euch hab ich schon hier geschrieben wie's mir auf der Reise ging oh, war ich doch bei euch geblieben war ich nicht, wo ich jetzt bin.

Liebe Freunde, was ich schreibe nehmet's nun zur Warnung an besser ist's zu Haus zu bleiben als sich drüben machen d'ran.

Übel geht es mir noch immer seit ich in den Staaten bin have written to you before

Of our plight on the voyage here,

Oh if only I'd stayed with you,

I wouldn't be where I am now.

Dear friends, what I am writing,

Take it as a warning now,

Better it is to stay at home

Than to chance your luck out here.

I've been in such a bad way

Ever since coming to the States, 
als ich auf dem Meer tat schwimmen da war schon fast alles hin.

Gott im Himmel, schau hernieder sieh an unsere große Not schenk uns deine Hilfe wieder denn sonst sind wir alle tot.
As I floundered on the high seas,

That was almost the end of $i$.

God in heavan, look down on us,

See our great need,

Grant us your help again,

Or we will all surely die. ${ }^{13}$

Another song group of the nineteenth century which Germany and Ireland have in common is anti-recruitment songs. The song "Ich bin Soldat, doch bin ich es nicht gerne" from 1872 is an account of disenchantment with life in the army and passes a moral verdict on war. Revived in both the East and West German song movements, it is unambiguously anti-militaristic with clear politically pacifistic and internationalist sentiments:

Ich bin Soldat, doch bin ich es nicht gerne, als ich es ward, hat man mich nicht gefragt. Man riß mich fort, hinein in die Kaserne, gefangen ward ich, wie ein Wild gejagt. $J a$, von der Heimat, von des Liebchens Herzen mußt' ich hinweg, und von der Freunde Kreis; denk ich daran, fühl ich der Wehmut Schmerzen, fühl in der Brust des Zornes Glut so heiß.

Ich bin Soldat, doch nur mit Widerstreben, ich lieb ihn nicht, den blauen Königsrock. Ich lieb es nicht, das blut'ge Waffenleben, mich zu verteid'gen wär genug ein Stock. O sagt mir an, wozu braucht ihr Soldaten? Ein jedes Volk liebt Ruh' und Frieden nur; allein aus Herrschsucht und dem Volk zum Schaden laßt ihr zertreten, ach, die gold'ne Flur!

Ich bin Soldat, muß Tag und Nacht marschieren, statt an der Arbeit, muß ich Posten stehn.

Statt in der Freiheit, muß ich salutieren und muß den Hochmut frecher Burschen sehn. Und geht's ins Feld, so muß ich Brüder morden, von denen keiner mir zuleid was tat; dafür als Krüppel trag ich Band und Orden, und hungernd ruf ich dann: "Ich war Soldat!"

Ihr Brüder all', ob Deutsche, ob Franzosen, ob Ungarn, Dänen, ob vom Niederland, ob grün, ob rot, ob blau, ob weiß die Hosen,
A soldier am I, but don't like to be, When I was made one, they didn't ask me. They took me away and brought me here, Hunting me like they would some deer. My home and my sweetheart I had to forgo And the group of friends I cherish so. My heart is heavy, painfully sad, and with the fire of anger mad.

A soldier am I, it's not my choice, gainst the king's blue garb I raise my voice. The blood-work of weapons is not mine, for my defense a stick would do fine. Tell me what you need soldiers for when all the people love peace and hate war. The thirst for power harms us all, lets golden fields get crushed and fall.

A soldier am I, must march night and day, instead of working, on guard I stay.

I can't be free, have to salute, and pay to arrogance my tribute.

Once we're in battle, they force me to slay brothers who never before crossed my way. A cripple with medals, I shall shout; I'm an ex-soldier, my belly growls loud.

My brothers, Germans, Frenchmen, Danes, men from Hungary, and the Netherlands, be red or green or blue your pants,

13 Folkländer 1982, transl. by D. Robb. 
gebt euch statt Blei zum Gruß die Bruderhand! Auf, laßt zur Heimat uns zurückmarschieren, von den Tyrannen unser Volk befrei'n; denn nur Tyrannen müssen Kriege führen, Soldat der Freiheit will ich gerne sein! don't greet with lead, greet with your hands. Let's march back home, and let us see that our people can be free. Just tyrants benefit from war. $A$ soldier for freedom I'll be evermore. ${ }^{14}$

The one striking difference between recruitment songs in Germany and Ireland is that while the German variants tend to be matter-of-fact and less personal, such songs in Ireland often constitute a narrative in ballad form where a story unfolds around a central, often named, character. One example is the song "Pat Reilly", popularised by the 1970s folk group Planxty:

It bein' on a Monday morning, it bein' our pay day

We met Sergeant Jenkins at our goin' away

He says to Pat Reilly "You are a handsome young man

Will you come to John Kelly's where we will set a dram"

And while we sat there boozin' and drinkin' our dram He says to Pat Reilly "You are a handsome young man I'd have you take the bounty and come along with me

To the sweet County Longford, strange faces there you'll see"

"Oh no kind sir, a soldier's life with me would not agree Nor neither would I bind myself down from my liberty For I lived as happy as a prince, my mind does tell me so So fare thee well, I'm just goin' down, my shuttle for to throw.

"Oh are you in a hurry, are you goin' away?

Or won't you stop and listen to these words I'm goin' to say

Perhaps now Pat Reilly, you might do something worse

Than to leave your native country and enlist in the Black Horse"

Oh it's I took the bounty, the reckoning was paid

The ribbons were brought out, me boys, and into my cockade

It's early the next morning we all were made to stand

Before our grand general with hats all in our hands

He says to Pat Reilly "You are a little too low

With some other regiment I fear you have to go"

"I may go where I will, I have no-one to mourn

For my mother is dead, me boys, and never will return"

It's not in the morning that I sing this song

But it's in the cold evening as I march alone

14 Steinitz 1979, vol. 1: 400-401; see also Pinkert-Saelzer 1997: 65-66. 
With me gun o'er my shoulder I bitterly do weep

When I think of my true love that now lies fast asleep

My blessing on my mother that reared me neat and clean

But bad luck to my father that made me serve the Queen

Oh had he been an honest man and learned to me my trade

I would never have enlisted nor worn the cockade $e^{15}$

In general the balladesque narrative with a story line does not occur to the same extent in the German soldiers or recruitment songs, which are more generalised accounts, not tailored to the individual personality of a central character (e.g. Pat Reilly). In particular the theme of drinking that lead to a character's undoing is generally missing from the German songs. In „Wo soll ich mich hinwenden” (Where shall I turn to), for example, a song that appears in several sources from the 1840s up until the First World War, the subject is press ganged while sleeping in his bed:

Wo soll ich mich hinwenden

Bei der betrübten Zeit?

An allen Ort und Enden

Ist nichts als Krieg und Streit.

Rekruten fanget man,

So viel man haben kann;

Soldat muß alles werden,

Es sei Knecht oder Mann.

Mit List hat man mich g'fangen

Als ich im Bette schlief;

Da kam der Hauptmann gegangen,

Ganz leise auf mich griff:

"Ei Bruder! Bist du da?

Von Herzen bin ich froh!

Steh' nur auf, Soldat mußt werden,

Das ist nun einmal so!"

So bin ich nun gefangen,

Mit Eisen angelegt;

Als wär' ich durchgegangen.

So hat man mich belegt.

Ach Gott, verleih' Geduld,

Ich bitt' um deine Huld!

Mein Schicksal will ich tragen,

Vielleicht hab' ich's verschuld't. [...]
Where shall I turn to

In this sad time?

Everywhere you look

There's nothing but war and strife.

They catch recruits

As many as they can;

You have to be a soldier,

Whether you're a servant or a man.

They used their cunning to get me

As I was asleep in bed;

The captain came up

And seized me quietly:

"Hey brother! Are you there?

I'm glad from the bottom of my heart!

Get up, it's time to be a soldier,

That's just the way it is!"

So they've caught me now,

And clapped me in irons;

As if I would have bolted

So they reigned me in.

Oh God, give me patience,

I ask for your grace!

I'll bear my fate,

Maybe it's my own doing. ${ }^{16}$

15 Transcribed from the singing of Andy Irvine on the LP Planxty 1973.

16 Steinitz 1979, vol 1: 335; see also Rohland 1967, transl. by D. Robb. 
The above example shows that the more personal narrative ballad form does exist in German folk songs. But they contain less of the happy-go-lucky but ultimately self-deprecating escapades of the central character which (as in the case of Pat Reilly) often involve drunkenness or personal misdemeanour with negative consequences.

The songs of the nineteenth century travelling craftsmen in Germany on the other hand do contain references to drink and adventure but, again, constitute less of a developing narrative. In "Lustig lustig" the unemployed craftsmen travel from town to town. Visual imagery of the various towns and buoyant spirits are conveyed but there is little detail of individual experience. The references to drinking or procuring women are more general:

Ja lustig, lustig ihr lieben Brüder, so leget all' eure Sorgen nieder, und trinkt dafür ein gut Glass Wein.

Auf die Gesundheit aller Brüder, die da reisen auf und nieder, dies soll unsre Freude sein.
Let's have fun, my dear brothers,

Time to lay down all your worries

Drink instead a good glass of wine.

To the health of all our brothers, Who travel round, up and down the country, This will be our joy today.

Refrain: Denn unser Handwerk das ist verdorben, Chorus: die letzten Saufbrüder sind gestorben, es lebet keiner mehr als ich und $d u$.

In Lübeck hab ich es angefangen, nach Hamburg stand dann mein Verlangen, Das schöne Bremen hab ich längst gesehen. Ich wollte Wismar und Rostock sehen, Und dann weiter nach Strahlsund gehen, Da liegt Rügen in der See.

[...]

Und wer dies alles hat gesehen, der kann getrost nach Hause gehen, und nehmen sich ein junges Weib.

Schlagt ein die Fässer und laßst es laufen, heute heißt es wacker saufen, denn solch ein Himmelreich ist nah.
For our craft it has been run down, The best drinkers have all passed away. There's noone here left but you and me.

I started off in the port of Lübeck, My desire took me on to Hamburg, I saw the beautiful Bremen too. Wismar and Rostock were my next stops, Then I sailed along to Strahlsund, There lies Rügen in the sea.

[...]

And when you've set eyes on all these places, You should go home feeling happy, And take yourself a good young bride.

Smash in the barrels and let the beer run, Now it's time for serious drinking, That's our kingdom of heaven. ${ }^{17}$

Another song "Förder niemand, mein Schicksal zu hören", popularised by the group Zupfgeigenhansel in the late 1970s, is an historical document of the hardships and the prejudice encountered by the German travelling craftsmen of the first half of the $19^{\text {th }}$ century. At the same time it romanticises the freedom of the vagabond existence. There

17 Text sung in the Rostock folk scene and written down by author, 1982-83, transl. by D. Robb. 
is a narrative, but it does not develop with a story-line, consisting rather of short general observations on the plight of the travelling man:

Fordre niemand mein Schicksal zu hören Von euch allen, die ihr in Arbeit steht. Ja wohl könnte ich Meister beschwören, Es wär doch bis morgen schon zu spät. Auf der Wanderschaft lustigen Tagen Setzt ich Kleider und Reisegeld zu. So ist mir denn nun weiter nichts zu tragen Als mein Rock und mein Stock und die Schuh.

Keine Hoffnung ist Wahrheit geworden Selbst in Schlesien war alles besetzt. Als ich reiste von Frankfurt nach Norden, Ward ich stets von Gendarmen gehetzt. Von Stettin aus nach Hause geschrieben, Ging ich dennoch Berlin erst noch zu. So ist mir denn nichts mehr geblieben Als mein Rock und mein Stock und die Schuh.

In der Heimat darf ich mich nicht zeigen, Denn dahin ist das Geld und der Rock. Laßt mich meinen Namen verschweigen, Denn sonst droht mir ein knotiger Stock, Statt in Betten in Wäldern gebettet, $O$ ich hatte nur wenige Ruh. So hab ich denn in der Fremde nichts gerettet Als die Hosen und zerissene Schuh.
Don't ask to hear my story

All those of you who are in work. I could plead with a master But it would be too late by the morn. For the joyful days of wandering I gather my clothes and money. And I have nothing else to carry Than my coat and my stick and my shoes.

Lack of hope has become reality Even in Silesia everything was full. As I travelled from Frankfurt up north I was constantly hounded by the law. I wrote home from up in Stettin Though I first went down to Berlin. And I've nothing left to show Than my coat and my stick and my shoes.

I can't show myself in my home land As I've lost my coat and my money.

I have to keep my name quiet Or I'll get beaten by a knotted stick. Instead of beds I sleep out in forests Where I don't get much peace. And I've saved nothing in this wilderness Than my pants and my worn out old shoes. ${ }^{18}$

This more generalised as opposed to an individual narrative contrasts, for example, with the Irish craftsman ballad "The Longford Weaver". This tells the tale of a man who leaves work and spends all his wages in Nancy's alehouse only to wake up with a hangover, swearing never to make the same mistake again:

These five long quarters I have been weaving and for my weaving I was paid down.

I bought a shirt in the foremost fashion, all for to walk up thro' Longford town. I walked up and thro' Longford city, where Nancy's Whiskey I chanced to smell. I thought it fun for to go and taste it,

18 See Zupfgeigenhansel 1995, transl. by D. Robb. 
these five long quarters I've liked it well.

I entered into a little alehouse

begged Nancy's pardon for making free

and Nancy met me at every corner,

You're hearty welcome, young man, says she.

We both sat down at a little table,

we looked at each other a little while,

we both sat down at a little table

and Nancy's whiskey did me beguile.

I found meself then in a little parlour,

I found meself then in a little bed,

I tried to rise, but I was not able

for Nancy's whiskey it held down me head.

When I arose, aye, the following morning,

I asked the reckoning I had to pay.

It's fifteen shillings for ale and porter,

come pay it quickly now and get away.

I put the moneys out on the table

saying I'll leave this money down with the rest

and I'll drink a health to every young man

and the wee lassie that I love best.

And I'll go home, I'll begin me weaving,

I'll steer me shuttle another while,

and if I live for another season,

it's Nancy's whiskey will not me beguile. ${ }^{19}$

It is clear in comparing folk songs of two different countries with separate historical and political conditions that aspects of commonality can only go so far. It is nonetheless also clear that class relationships and consequences of capitalist world trade in the nineteenth century affected people in similar ways across Europe, resulting in songs dealing with universal themes. In the post-World War II history of Germany it was highly significant that singers made the discovery of this other "democratic" folk song tradition. Establishing the aforementioned aspects of commonality with European neighbours such as Ireland helped the German nation to redefine its cultural self-image which had been so badly tarnished by the Nazis.

19 Irvine 1980. 


\section{REFERENCES AND SOURCES}

Cleary, Thomas

1888 Songs of the Irish Land War. Dublin: W. P. Swan.

Folkländer

1982 Wenn man fragt, wer hat's getan. Amiga LP 845219.

Irvine, Andy

1980 Rainy Sundays...Windy Dreams. Tara LP 3002.

James, Barbara and Walter Mossmann

1983 Glasbruch 1848. Flugblattlieder und dokumente einer zerbrochenen Revolution. Darmstadt and Neuwied: Luchterhand.

O’Hearn, Denis

2001 The Atlantic Economy. Britain, the US and Ireland. Manchester: Manchester University Press.

Pinkert-Saelzer, Inke (ed.)

1997 German Songs. Popular, Political, Folk, and Religious. (Engl. transl. by Sabine Tober.) New York: Continuum.

Planxty

1973 The Well Below the Valley. Polydor LP (re-release Shanachie 79010).

Robb, David (ed.)

2007 Protest Song in East and West Germany since the 1960s. Rochester/NY: Camden House.

Rohland, Peter

1967 48er Lieder - Lieder deutscher Demokraten. Teldec LP T75508.

Sparling, H. Halliday

1888 (1890?) Irish Minstrelsy. Being a Selection of Irish Songs, Lyrics and Ballads. New York and London: White and Allen.

Steinitz, Wolfgang

1979 (1954, 1962) Deutsche Volkslieder demokratischen Charakters aus sechs Jabrbunderten [German Folk Songs of a Democratic Character from Six Centuries]. Vols. 1 and 2. Berlin: Verlag das europäische Buch. Sonderausgabe für Zweitausendeins.

Süverkrüp, Dieter

19731848 - Lieder der deutschen Revolution. LP Pläne S11102.

Wright, Robert L. (ed.)

1975 Irish Emigrant Ballads and Songs. Bowling Green, Ohio: Bowling Green University Popular Press.

Zupfgeigenhansel

1995 Alle die dies Lied gesungen. Jumbo CD 4401332. 


\section{SKUPNA EVROPSKA PESEMSKA DEDIŠČINA V IRSKIH IN NEMŠKIH PESMIH 19. STOLETJA}

Članek predstavlja vsebinske podobnosti med nemškimi in irskimi ljudskimi pesmimi 19. stoletja, posebno še v obdobju revolucionarnih sprememb ok. leta 1848. Zbirki t. i. nemških 'demokratičnih" ljudskih pesmi z naslovom Deutsche Volkslieder demokratischen Charakters aus sechs Jahrhunderten (Steinitz 1954 in 1962) (Nemške ljudske pesmi z demokratičnim značajem iz šestih stoletij), kaže na to, da ima Nemčija tudi drugačne pesmi kakor le nazadnjaške, nacionalistične ljudske pesmi, ki so bile nato zlorabljene v času nacizma. Čeprav lahko vidimo jasne podobnosti med irskimi in nemškimi pesmimi 19. stoletja, ki pojejo o izkoriščevalskih gospodarjih, izseljevanju, lakoti in vojaških vpoklicih, pa so opazne razlike med Nemčijo kot deželo izrazite industrializacije in Irsko, ki je bila takrat predvsem ruralna dežela. Besedila nemških protestnih pesmi vsebujejo več razredne zavesti, podobne irske pa tematizirajo moč vere in tudi nacionalno osvoboditev spod zunanjega zavojevalca. Pripovedni način in slog pesnjenja sta različna (npr. bolj osebna pripoved irskega junaka, ki gre velikokrat na pijanske pohode), je pa veliko dokazov skupnega načina izražanja v pesmih in glasbi pri obeh narodih. To je potrdila kulturna izmenjava med narodoma z gostovanji različnih irskih "ljudskih" pevcev in glasbenih skupin v Nemčiji po letu 1970.

Dr. David Robb, School of Languages, Literatures and Performing Arts, Queen's University of Belfast, Belfast BT7 1NN, North Ireland, d.robb@qub.ac.uk 